\title{
Effects of hyperthermia on DNA repair pathways: one treatment to inhibit them all
}

\author{
Arlene L. Oei ${ }^{1,3+}$, Lianne E. M. Vriend ${ }^{2 \dagger}$, Johannes Crezee ${ }^{3}$, Nicolaas A. P. Franken ${ }^{1,3}$ and Przemek M. Krawczyk ${ }^{2^{*}}$
}

\begin{abstract}
The currently available arsenal of anticancer modalities includes many DNA damaging agents that can kill malignant cells. However, efficient DNA repair mechanisms protect both healthy and cancer cells against the effects of treatment and contribute to the development of drug resistance. Therefore, anti-cancer treatments based on inflicting DNA damage can benefit from inhibition of DNA repair. Hyperthermia - treatment at elevated temperature - considerably affects DNA repair, among other cellular processes, and can thus sensitize (cancer) cells to DNA damaging agents. This effect has been known and clinically applied for many decades, but how heat inhibits DNA repair and which pathways are targeted has not been fully elucidated. In this review we attempt to summarize the known effects of hyperthermia on DNA repair pathways relevant in clinical treatment of cancer. Furthermore, we outline the relationships between the effects of heat on DNA repair and sensitization of cells to various DNA damaging agents.
\end{abstract}

Keywords: Hyperthermia, DNA damage, DNA repair, Chemotherapy

\section{Introduction}

Hyperthermia - treatment above temperatures that are physiologically optimal - affects cells and tissues on countless levels, by directly altering the physical properties of cellular components and by evoking counteractive cellular responses. Among other effects, heat causes DNA, protein and membrane damage, interferes with cell cycle, DNA and protein synthesis and may result in cell death, either directly or by triggering apoptotic pathways [1-5].

Early research demonstrated that except for the cytotoxic potential, hyperthermia can sensitize cells to DNA damaging agents. Indeed, elevated temperature, applied in combination with various anti-cancer drugs or radiation, has been shown to eradicate transformed cells in vitro and to inhibit tumor growth in animal models [6-13]. It was also speculated, based on results obtained using biochemical methods, that heat may induce DNA damage directly [14-16]. In the subsequent decades, an extensive body of data confirmed that hyperthermia is a

\footnotetext{
*Correspondence: p.krawczyk@amc.uva.nl

${ }^{\dagger}$ Equal contributors

${ }^{2}$ Van Leeuwenhoek Centre for Advanced Microscopy (LCAM)-AMC, Department of Cell Biology and Histology, Academic Medical Center, University of Amsterdam, Meibergdreef 15, 1105 AZ Amsterdam, The Netherlands

Full list of author information is available at the end of the article
}

powerful sensitizer to many agents that interfere with DNA metabolism or cause DNA damage, suggesting that it might directly interfere with DNA repair. However, how hyperthermia sensitizes cells to DNA damaging agents remained unclear. This changed gradually during the last two decades. With the introduction of advanced fluorescence imaging and molecular biology techniques in the 1990s came deeper understanding of DNA repair networks that, in turn, facilitated interpretation of results. During the last decade a number of important findings cemented the position of hyperthermia research within the DNA repair field and first large clinical trials clearly demonstrated the benefits of hyperthermia as adjuvant in clinical treatment of cancer [17-19] and stimulated research and development of new treatment approaches, such as hyperthermia-mediated drug release [20]. Nevertheless, the effects of hyperthermia on DNA repair are still not sufficiently understood.

It is clear that cytotoxic or sensitizing effects of hyperthermia cannot be attributed to deactivation of a single DNA repair mechanism, but rather to influencing many pathways, on multiple levels. Although this may hamper the interpretation of experimental data, the pleiotropic effects of heat on DNA repair may be extremely beneficial in the clinical settings. Therefore, 
understanding how heat interacts with the DNA repair networks will help in improving the existing and designing novel (combination) therapies. This review attempts to categorize the influence of hyperthermia on the known DNA repair pathways, with special attention to those pathways relevant in cancer treatment. Due to space and subject limitations, the effects of hyperthermia on other metabolic pathways or tissues and organs are not discussed, even though they might be as (or more) important in anti-cancer treatments.

One important factor that generally confounds analysis of available literature data is that different thermal doses are used in different studies. The thermal dose depends on the temperature and duration of treatment so that thermal dose equivalent at a given temperature can in principle be calculated using Arrhenius equations. For instance, cumulative equivalent minutes at $43{ }^{\circ} \mathrm{C}\left(\mathrm{CEM}_{43}\right)$ can be calculated to compare results of experiments or clinical treatments performed at different temperatures [21]. Accordingly, except for relatively high $\left(>45{ }^{\circ} \mathrm{C}\right)$ temperatures, in principle the effects observed at a given temperature can be achieved by using a lower temperature and longer incubation time. We therefore intentionally do not limit our review to clinically relevant temperatures $\left(<43{ }^{\circ} \mathrm{C}\right)$. Such approach allows inclusion of a broader spectrum of hyperthermia effects but caution should be exercised when directly comparing results of experiments performed at different temperatures.

\section{Direct induction of DNA damage by hyperthermia}

It is generally accepted that hyperthermia inhibits DNA repair. However, the fundamental question whether hyperthermia directly induces DNA damage has not been definitively answered. Early studies showed that hyperthermia may induce DNA breaks and chromosomal aberrations, either by causing protein denaturation or by interfering with replication [14-16, 22-25]. Increased levels of 8-oxoguanine, apurinic sites and deaminated cytosines have also been detected after heat treatment [26]. Other studies showed that hyperthermia does not cause DNA damage in absence of additional stimuli. However, heat seemingly increased the levels of single strand breaks (SSBs) and double strand breaks (DSBs) during processing of damage induced by ionizing radiation, possibly by impairing the repair of corrupted bases [24, 27, 28]. Nearly a decade later it was reported that heat $\left(>41.5^{\circ} \mathrm{C}\right)$ triggers focal phosphorylation of histone $\mathrm{H} 2 \mathrm{AX}$, similar to the formation of the so-called ionizing radiation induced foci (IRIF) [29-31] that are generally considered to occur in response to DSBs [32, 33]. Moreover, this response was observed at relatively mild temperatures and the number of foci was proportional to thermal dose and cell killing.
Interestingly, the induction of phospho- $\mathrm{H} 2 \mathrm{AX}(\gamma \mathrm{H} 2 \mathrm{AX})$ foci was suppressed by prior heat treatment, resembling the known phenomenon of thermotolerance [34]. The authors suggested that the proposed induction of DSBs by hyperthermia may not be direct, but rather a result of nicks induced in close proximity on opposing DNA strands [29].

Later studies confirmed the induction of $\gamma \mathrm{H} 2 \mathrm{AX}$ and $\mathrm{MDC} 1$ foci by hyperthermia $\left(43-45.5^{\circ} \mathrm{C}\right)$ and showed its dependence on DSB signaling factor ATM [30, 35-38]. However, hyperthermia-induced foci did not recapitulate all characteristics of IRIF in that they failed to co-localize with 53BP1 or SMC1. Importantly, neither DNA damage, nor chromosome aberrations were detected in these studies, suggesting that heat may induce chromatin changes that in turn trigger DNA damage responses (DDR) in the absence of actual DNA damage [35]. Such triggering by different stimuli has indeed been observed earlier [39-42].

Adding to the debate, Velichko and colleagues recently reported that two different patterns of $\gamma \mathrm{H} 2 \mathrm{AX}$ foci can be discerned in hyperthermia-treated cells $\left(42-45.5^{\circ} \mathrm{C}\right)$ : the larger IRIF-like foci in $\mathrm{G}_{1}$ - and $\mathrm{G}_{2}$-phase cells and the smaller but more numerous foci in S-phase cells [43]. Even more surprisingly, hyperthermia-induced DSBs were detected in heated $G_{1} / G_{2}$ cells but not in S-phase cells, while the inverse was true for SSBs. Furthermore, the authors demonstrated inhibitory effects of heat on replication fork progression. The absence of DSBs in cells heated in S-phase can be caused by suppression of replication fork progression that might, in turn, prevent DSB formation [44]. The S-phase specific 'protective' foci may thus mark sites of stalled replication forks that are not yet converted to DSBs. On the other hand, the foci in non-S phase cells could mark DSBs that were directly induced by heat or, alternatively, persistent DSBs [45] that were unmasked by heat-related chromatin changes. This latter explanation may be difficult to prove since only a limited number of persistent DSBs have been observed earlier while hyperthermia can induce a large number of foci. Moreover, the chromatin domains containing persistent DSBs are decorated with 53BP1 [45], in contrast to heat-induced foci [35].

Clearly, the question whether heat directly induces DSBs is far from resolved. The majority of studies failed to detect DSBs or chromosome aberrations in heated cells by direct methods [46]. Most reports that did confirm induction of DSBs by heat rely on indirect assays such as phosphorylation of H2AX or accumulation of repair-related proteins. Some other studies confirmed DSB induction by direct methods and showed that phosphorylation of $\mathrm{H} 2 \mathrm{AX}$ correlates with cell killing and thermotolerance. More sensitive and specific methods to directly detect DNA DSBs and SSBs may be required to settle the long-standing dispute. 


\section{DNA damage signaling and cell cycle checkpoint activation}

Even though it is far from certain whether hyperthermia can directly damage DNA, the triggered signaling resembles, to some extent, the responses caused by DNA damaging agents (see also previous section). In mammalian cells, such signaling can initiate checkpoints which interrupt the cycle progression to provide time for DNA repair and are thus essential for the maintenance of genomic integrity [47]. The mammalian checkpoints started in response to DNA damage are managed by the two master kinases, ATM and ATR $[48,49]$. ATM is thought to be activated, with help of the the MRN (MRE11/RAD50/NBS1) complex, by DSBs, mainly in $G_{1}$-phase $[47,50]$. ATR chiefly responds to exposed single stranded DNA at stalled replication forks in S-phase, in a manner that is at least partly dependent on ATM $[51,52]$. Both ATM and ATR, as well as the DNA-PK kinase, phosphorylate histone H2AX (see also previous section) and many other repair factors in chromatin domains surrounding the damaged DNA. This, in turn, triggers accumulation of multiple DNA repairrelated proteins at damaged chromatin, further propagation of the damage signal and activation of the appropriate cell cycle checkpoints via mechanisms dependent on Chk1, Chk2, p53, CDC25a, WEE1 and other factors [47].

Mammalian cells display varying thermosensitivity, depending on the cell cycle phase in which they were heated $[53,54]$. In general, $G_{1}$-phase cells are relatively heat resistant and do not show any damage upon microscopic examination. S-phase cells are more sensitive and chromosomal damage is observed $[55,56]$. The highest heat sensitivity can be observed during the M-phase, with damage of cellular mitotic apparatus leading to inefficient cell division and polyploidy. Hyperthermia induces a 'slow mode of cell death' in S- and M-phase, while cells heated during $G_{1}$-phase may enter a 'rapid mode of death' $[54,57]$. These variations in sensitivity between the different cell cycle phases suggest diversity of molecular mechanisms regulating cell death following hyperthermia, which may indicate involvement of various checkpoint mechanisms [53, 58, 59]. However, the influence of hyperthermia on cell cycle progression is not well understood. Early studies showed increase in length of all phases and arrest at the $G_{1} / S$ transition [60-62], but the underlying mechanisms were unclear. More recent work confirmed activation of cell cycle checkpoints by $42-46^{\circ} \mathrm{C}$ heating [63] and implicated activation of ATM and a subset of its downstream targets, including p53, independently of the MRN complex [35, 64] (see also previous section). Another study reported activation of p53 via the thioredoxin-dependent redox state and modulation of checkpoint regulators Gadd45a and $\mathrm{Cdc} 2$ at $41{ }^{\circ} \mathrm{C}$ [65]. On the other hand, hyperthermia seems to disturb early steps in cellular responses to radiation-induced damage, as delayed formation of 53BP1 foci and phosphorylation of SMC and Chk2 have been reported after treatment at $43^{\circ}$ $\mathrm{C}$ [66]. This may be surprising, since ATM directly phosphorylates Chk2 in response to heat [64, 67]. Thus, while heat treatment alone may activate cell cycle checkpoints via the ATM kinase, it can apparently also delay signaling triggered by exogenously induced DNA damage.

ATR and Chk1 are also activated by heat $\left(42.5-45{ }^{\circ} \mathrm{C}\right)$, reportedly to a larger extent than the ATM/Chk2 branch of the DDR, and the ensuing signaling cascade causes $\mathrm{G}_{2} / \mathrm{M}$ arrest which can be abrogated by inhibition of Chk1 [67, 68]. Chk1 activation is dependent on Rad9, Rad17, TopBP1 and Claspin, which play important roles in activation of ATR at stalled replication forks [69]. However, similarly to heat-induced ATM signaling, not all targets of ATR are activated as neither FancD2 monoubiquitination nor RPA32 phosphorylation were observed [67]. Hyperthermia $\left(43-48{ }^{\circ} \mathrm{C}\right)$ also influences $\mathrm{S}$-phase progression by directly inhibiting multiple processes related to replication [70-72]. Contributing to these effects is the release of nucleolin from the nucleolus which stimulates RPA-nucleolin interactions and may thus limit RPA involvement in replication. It seems feasible that this could, in turn, cause slowing or collapse of replication forks and initiate ATR signaling. In the context of S-phase, the activation of cell cycle checkpoint might therefore be a protective response mitigating the effects of hyperthermia on replication progression. Indeed, mammalian cells are exceptionally sensitive to heat in S-phase and at least part of hyperthermia-related cytotoxicity observed in S-phase cells can be alleviated by inhibition of replication [44]. Both ATM and ATR, as well as DNA-PK, seem to propagate damage signaling in response to heat by phosphorylating histone H2AX [43], with ATM/ATR responding to the presumed heatinduced DNA damage and DNA-PK reacting to heatinduced replication arrest (see also previous section). Intriguingly, the DNA-PK (but not ATR)-mediated H2AX phosphorylation may protect replication forks from collapse and DSB formation [43].

Based on the effects described above, it could be predicted that hyperthermia sensitizes cells to agents that interfere with cell cycle (checkpoints). Indeed, after treatment with hyperthermia $\left(42{ }^{\circ} \mathrm{C}\right)$, antimitotic drugs like paclitaxel, nocodazole or Aurora A inhibitor showed increased toxicity. However, this was not due to activation of cell cycle checkpoints but, surprisingly, due to abrogation of the $\mathrm{M}$ checkpoint and forced mitotic exit, resulting in mitotic catastrophe [73]. Although hyperthermia (at $41.5^{\circ} \mathrm{C}$ ) also stimulates mitotic catastrophe in X-irradiated cells, this is accompanied by strengthening, rather than weakening, of radiation-induced $S$ and $G_{2}$ checkpoints [74]. It is not clear what mechanisms are responsible for the increased heat sensitivity of M-phase 
cells [75], but DNA damage repair is limited in this phase [76], which could explain heat-sensitivity if DNA damage is directly caused by hyperthermia.

Concluding, the effects of hyperthermia on cell cycle progression and checkpoint activation seem to be mediated, to a large extent, by ATM and ATR, the two factors that primarily regulate checkpoints in response to DNA damage. This could indicate that heat induces DNA damage, which in turn activates the DDR cascade. The preferential activation of ATR/Chk1 [67] suggests that, if DNA lesions are indeed induced by heat, they might be related to inhibited or corrupted replication forks. On the other hand, the differences in patterns of signaling initiated by heat, as compared to signaling triggered by direct DNA damage, may suggest involvement of other unidentified mechanisms, such as those related to chromatin changes [77].

\section{Excision repair}

Excision repair in mammalian cells encompasses mechanisms that remove corrupted bases or nucleotides and fix DNA mismatches. Excision repair can be subdivided into base excision repair (BER), nucleotide excision repair (NER) and mismatch repair (MMR), with BER and NER proceeding via a SSB intermediate and thus sharing the final steps with SSB repair mechanisms.

BER constitutes the main pathway for the repair of DNA lesions induced by oxidizing or alkylating agents, as well as by endogenous metabolic activities. BER is active throughout the cell cycle and executed by a number of proteins that include DNA glycosylases, apurinic/apyrimidinic endonucleases, phosphatases, phosphodiesterases, kinases, polymerases and ligases [78]. BER is initiated by various glycosylases which recognize and remove the damaged bases and create abasic (AP) DNA sites. AP endonucleases (APE1 in human cells) then recognize and cleave AP sites and recruit DNA polymerases to restore the gaps, via a SSB intermediate, where BER and SSB repair pathways converge. Tens of thousands of damaged bases per day must be fixed in a mammalian cell, thus BER has evolved as a fast and efficient mechanism of paramount importance for maintaining the genomic integrity [78].

It has been suggested that BER might be the main target of heat at temperatures above $43.0{ }^{\circ} \mathrm{C}[79,80]$. Indeed, a measurable inhibition of base excision in X-irradiated cells was observed after hyperthermia [81]. Additionally, although hyperthermia treatment $\left(43-45^{\circ} \mathrm{C}\right)$ did not induce DNA damage by itself, it increased the amount of damaged bases and DSBs in X-irradiated cells [27], possibly by inhibiting BER and thus indirectly stimulating conversion of damaged bases to DSBs. Hyperthermia $\left(>41.5^{\circ} \mathrm{C}\right)$ has also been shown to affect the activity of DNA Pol $\beta$, an important BER factor [82-86]. However, the lack of correlation between Pol $\beta$ activity and hyperthermic cell killing has also been reported [87]. In contrast to Pol $\beta$, effects of hyperthermia on its partner XRCC1 that is involved in later steps of BER and in SSB repair have not been explored, but it is intriguing that the molecular chaperone HSP90, part of the cellular responses to heat shock, influences DNA repair by regulating interactions between Pol $\beta$ and XRCC1 [88]. It could be speculated that upon hyperthermia treatment HSP90 is required to chaperone its other client proteins, which could result in decreased mediation of XRCC1-Pol $\beta$ interactions. Recently it has been confirmed that mild hyperthermia $\left(42{ }^{\circ} \mathrm{C}\right)$ directly impairs BER, at least partially by affecting the cellular glycosylase activities [89]. In particular, hyperthermia inactivates 8-oxoguanine DNA glycosylase (OGG1) by depleting it from the nucleus and eliciting its proteasomemediated degradation. The inhibition of OGG1 then likely contributes to heat-induced radio- or chemosensitization.

On the other hand, siRNA-mediated downregulation of AP endonuclease (APE1), a critical BER enzyme, failed to influence hyperthermic radiosensitization in HeLa cells, suggesting that BER is not affected by $41.5^{\circ} \mathrm{C}$ incubation [90]. It should be noted, however, that only about $70 \%$ downregulation of APE1 was achieved in this study and the residual protein levels might be sufficient to sustain (partial) BER activities. Moreover, the contribution of APE1 to cellular radiation responses is unclear and while some studies show that decreased APE1 levels correlate with increased radiosensitivity others show the opposite effects [90, 91].

Nucleotide excision repair (NER) is involved in excision mechanisms that remove DNA damage like pyrimidine dimers and (6-4)photoproducts [92]. The influence of hyperthermia on NER has not been extensively explored, but one study showed reduced NER-associated strand incision and considerably delayed repair of thymidine dimers in cultured human fibroblasts and keratinocytes heated at $43{ }^{\circ} \mathrm{C}$. Additionally, the repair of UV-B-damaged plasmid DNA was lower if the transfected cells were exposed to heat [93].

One argument supporting the notion that hyperthermia interferes with NER stems from studies on sensitization to platinum-based compounds. Cisplatin and its derivatives, used widely in clinical cancer treatment, produce DNA interstrand cross-links that can be either repaired by the NER machinery or, after conversion to DSBs, by replicationcoupled repair [94-96]. A wide body of evidence indicates that $39-43{ }^{\circ} \mathrm{C}$ hyperthermia sensitizes cells to cisplatin [97-100], suggesting that NER may indeed be among heat targets. One study compared hyperthermia-mediated (40$41{ }^{\circ} \mathrm{C}$ ) sensitization to cisplatin in cells lacking the major NER factor XPA with wild-type cells [101]. Results showed comparable sensitization in both cell lines, leading to suggestion that NER plays no major role in this process. 
However, cisplatin-induced DNA lesions can also be repaired by pathways other than NER [95], which could explain these results, although these other pathways can also be affected by heat. Among modulatory effects of hyperthermia on cellular responses to cross-linkers is also suppression of cisplatin-induced XPC and XPA, as shown in human epithelial ovarian cancer xenografts incubated at $43{ }^{\circ} \mathrm{C}[102]$.

The effects of hyperthermia on MMR are even less explored. It has been shown that MMR factors hMLH1 and $\mathrm{hMSH} 2$ translocated from the nucleus into the cytoplasm in response to $41-42{ }^{\circ} \mathrm{C}$ heat shock [103]. This study also showed, by applying comet assay, that hyperthermia induces DNA damage. Surprisingly, in heat-shocked MMR-deficient cells less DNA damage was detected than in wild-type counterparts, for up to $4 \mathrm{~h}$ after treatment, but the DNA repair capacity $24 \mathrm{~h}$ after treatment remained unaffected. These results suggest that MMR may stimulate induction (or conversion) of DNA lesions by heat, but is not involved in repair.

The excision repair pathways interplay at restoring DNA lesions induced by many different classes of chemotherapeutics, including alkylating agents and antimetabolites [104-107]. Hyperthermia sensitizes cells to many of these agents (Table 1), providing support for the hypothesis that excision repair pathways are affected by heat. However, clear interpretation of experimental and clinical data is hampered by extensive overlap of these mechanisms during repair of various lesions. For instance, DNA damage caused by alkylating agents, either directly or during processing of the initial lesions, can be repaired by NER, BER, MMR, as well as by SSB and DSB repair pathways $[92,105,108]$ (Table 1 ).

\section{Non-homologous end joining}

Non-homologous end joining (NHEJ) is one of the major pathways to repair DSBs in mammalian cells. NHEJ is active throughout the cell cycle and rejoins the broken DNA ends without the requirement for homology or repair template [109]. Recently, two NHEJ subpathways have been discerned: the classical and alternative (or backup) NHEJ (alt-NHEJ). During the classical NHEJ (c-NHEJ), the Ku heterodimer is among the first factors that bind DNA ends. Upon binding, it becomes a scaffold for the subsequent recruitment of the end processing nucleases and ligases. As naturally occurring DSBs rarely result in clean DNA ends suitable for direct ligation, they are first processed by the Artemis/DNA-PKcs complex that provides various nucleolytic activities, and possibly by APLF and PNK. Ligation is then performed by the XLF/XRCC4/ DNA ligase IV complex and the recently discovered XLF/ XRCC4 paralog PAXX [110]. The Ku and ligase IVindependent alternative NHEJ may instead involve PARP1, XRCC1 and DNA ligases I or III [111]. While c-NHEJ is generally an accurate pathway, alt-NHEJ may be responsible for improper repair and formation of chromosome translocations in the absence of c-NHEJ $[112,113]$.

Table 1 DNA damaging chemotherapeutic agents interacting with hyperthermia

\begin{tabular}{|c|c|c|c|}
\hline Class & $\begin{array}{l}\text { Agent [with references to studies showing interaction } \\
\text { of the agent with hyperthermia] }\end{array}$ & Type of inflicted DNA damage & $\begin{array}{l}\text { Pathways involved in repair } \\
\text { [references] }\end{array}$ \\
\hline \multirow[t]{3}{*}{ Alkylating agents } & - triazenes (temozolomide $[182,183])$ & \multirow{3}{*}{$\begin{array}{l}\text { strand cross-links, adducts, DSBs } \\
\text { (indirect) }\end{array}$} & \multirow{3}{*}{$\begin{array}{l}\text { NER, BER, MMR, NHEJ, HR } \\
{[108,184]}\end{array}$} \\
\hline & $\begin{array}{l}\text { - nitrogen mustard derivatives (cyclophosphamide } \\
\text { [13, 185-191], melphalan [191-199]) }\end{array}$ & & \\
\hline & $\begin{array}{l}\text { - aziridine-containing (mitomycin C }[10,187,191 \text {, } \\
\text { 200-203]) }\end{array}$ & & \\
\hline $\begin{array}{l}\text { Alkylating-like platinum } \\
\text { compounds }\end{array}$ & $\begin{array}{l}\text { - cisplatin }[12,100,101,191,201,204-210] \text {, carboplatin } \\
\text { [211-214], oxaliplatin }[198,199,209,215]\end{array}$ & strand cross-links, DSBs (indirect) & $\begin{array}{l}\text { NER, BER, MMR, HR } \\
{[94,95,216,217]}\end{array}$ \\
\hline \multirow[t]{3}{*}{ Antimetabolites } & $\begin{array}{l}\text { - pyrimidine analogs (5-fluorouracil [218], gemcitabine } \\
[161,199,219])\end{array}$ & \multirow[t]{3}{*}{$\begin{array}{l}\text { SSBs, DSBs (indirect), oxidative } \\
\text { damage }\end{array}$} & \multirow[t]{3}{*}{$\begin{array}{l}\text { HR, MMR, NER } \\
{[148,161,220,221]}\end{array}$} \\
\hline & $\begin{array}{l}\text { - purine analogs (2-aminopurine [222], 6-thioguanine } \\
\text { [222]) }\end{array}$ & & \\
\hline & $\begin{array}{l}\text { - dihydrofolate reductase inhibitors (methotrexate } \\
[210,223])\end{array}$ & & \\
\hline Topoisomerase I poisons & $\begin{array}{l}\text { - camptothecin [224], B-lapachone [144, 145], } \\
\text { Irinotecan [199] }\end{array}$ & SSBS & BER, NER, NHEJ $[225,226]$ \\
\hline Topoisomerase II poisons & - intercalators (doxorubicin [187, 188, 227-230]) & DSBs & NHEJ, HR [231-233] \\
\hline \multirow[t]{3}{*}{ Radiomimetics } & - enediynes (neocarzinostatin [10]) & \multirow{3}{*}{$\begin{array}{l}\text { SSBs, DSBs, oxidative damage, } \\
\text { strand cross-links }\end{array}$} & \multirow{3}{*}{$\begin{array}{l}\text { HR, NHEJ, BER, } \\
{[136,137,234,235]}\end{array}$} \\
\hline & - bleomycin $[6,10,12,191,210,236,237]$ & & \\
\hline & - mitomycin C [10, 187, 191, 200-203] & & \\
\hline PARP inhibitors & - olaparib [150, 153], PJ-34 [150] & SSBs, DSBs (indirect) & HR, BER [238-240] \\
\hline
\end{tabular}


Whether NHEJ is inhibited by hyperthermia has been a subject of long debate. The initial evidence of NHEJ involvement can be found in data showing that hyperthermia sensitizes cells to ionizing radiation in $\mathrm{G}_{1}$-and $\mathrm{G}_{0}$-phase of the cell cycle, where mostly NHEJ mechanisms are responsible for repair of DSBs, although the degree of sensitization is increased in S- and M-phases [53, 114-116]. Later studies compared the degree of hyperthermia-mediated radiosensitization in wild-type and repair deficient Xrs- 5 cells in plateau phase of growth and found that these cells could no longer be radiosensitized by hyperthermia. The rationale behind these experiments was that if repair pathway $\mathrm{X}$ is an (exclusive) target of hyperthermia, (wild-type) cells with a proficient pathway X can be radiosensitized by hyperthermia. This is in contrast to cells with a defect in pathway $\mathrm{X}$ which would no longer be radiosensitized. Using this logic, it was concluded that the DNA repair pathway defective in Xrs- 5 cells is targeted by $43-45^{\circ} \mathrm{C}$ hyperthermia $[117,118]$. The deficiency in Xrs-5 cells was later attributed to the absence of a functional Ku protein [119-121], indirectly implicating NHEJ in heat-mediated radiosensitization. However, a number of subsequent studies showed no significant difference in sensitization of wild-type and NHEJ-deficient cell lines at similar temperatures (42.5$\left.45.5{ }^{\circ} \mathrm{C}\right)$ [122-126]. Further, chemical inhibition of DNA-PK activity potentiated hyperthermia-mediated radiosensitization [127] and stimulated heat-induced apoptosis [128]. To explain this discrepancy, it was proposed that the $\mathrm{Ku}$-independent alt-NHEJ pathway may instead be targeted by heat [129]. In log-phase cells, both c-NHEJ and alt-NHEJ pathways are active. Thus, in log-phase c-NHEJ-deficient cells, alt-NHEJ is still operational and, if this pathway is heat-sensitive, such cells could potentially be further sensitized by hyperthermia. In contrast, in plateau-phase cells alt-NHEJ seems severely compromised [130] and innate c-NHEJ deficiency would render such cells resistant to further heatinduced radiosensitization.

Although evidence of direct effects of hyperthermia on alt-NHEJ is lacking, effects on c-NHEJ factors have been observed by several groups. Studies showed heat-mediated inactivation of DNA binding by $\mathrm{Ku}$ and decreased activity of DNA-PK complex that correlated with the degree of radiosensitization, at temperatures of $44-45^{\circ} \mathrm{C}$ [131-133]. Additionally, incubation at $44.5^{\circ} \mathrm{C}$ induced aggregation of $\mathrm{Ku}$ in nuclei of human cells [134]. A recent study confirmed reversible repression of DNA-PK activity by $44{ }^{\circ} \mathrm{C}$ hyperthermia and reported considerable decrease in KU70 and KU80 protein levels, along with a more modest decrease in levels of BRCA1 and 53BP1 [135].

Hyperthermia $\left(>41.5^{\circ} \mathrm{C}\right)$ sensitizes cells to radiomimetic drugs such as bleomycin and neocarzinostatin that induce DSBs repaired by NHEJ mechanisms [6, 12, 136-139] (Table 1). One caveat in the interpretation of these experiments is that such drugs also induce SSBs and oxidative damage that may be repaired by other mechanisms or converted to DSBs and repaired by homologous recombination (see next paragraph) in the ensuing $S / G_{2}$-phase of the cell cycle. Interestingly, even though DSBs indirectly induced by inhibitors of Topoisomerase II are primarily repaired by NHEJ [140], heat not only fails to sensitize cells to Topoisomerase II inhibitor etoposide, but exerts protective effects [141]. It has been suggested that hyperthermia may prevent formation of Topoisomerase II cleavage complexes after etoposide treatment, thereby reducing the DSB burden in treated cells [141]. This is in contrast to Topoisomerase I and II inhibitor $\beta$ lapachone [142, 143], whose cytotoxicity is potentiated by $42{ }^{\circ} \mathrm{C}$ hyperthermia $[144,145]$.

Thus, although indirect genetic studies do not confirm NHEJ as an exclusive target of hyperthermia, other results clearly support the notion that NHEJ is among the affected DNA repair mechanisms.

\section{Homologous recombination}

Homologous recombination (HR) is the second DSB repair pathway of major importance in mammalian cells. HR requires a homology template, usually the sister chromatid, and is thus only active during $\mathrm{S}$ - and $\mathrm{G}_{2}$-phases. The first step in HR is the generation of 3' single-stranded DNA overhangs, driven by the MRN complex. RPA quickly coats the exposed single-stranded DNA but is later replaced by RAD51 with help of BRCA2. The RAD51 nucleoprotein filaments are crucial for the search for the homologous duplex DNA, strand invasion, and the formation of the so-called Holliday junctions. The invading strand is extended by DNA polymerases, which copy the missing DNA sequence from the homologous template DNA, and, after dissolution of the Holliday junctions, the ends are ligated together [146].

Similarly to NHEJ, the involvement of HR in hyperthermic radiosensitization has been debated. Early studies indirectly excluded HR as a sole target of $42-45{ }^{\circ} \mathrm{C}$ hyperthermia [147], since rodent cell lines defective in XRCC2 and XRCC3, important HR factors, were normally radiosensitized by hyperthermia $\left(43{ }^{\circ} \mathrm{C}\right)[80,148]$, as were HR-deficient chicken DT40 cells $\left(44^{\circ} \mathrm{C}\right)[147,149]$. However, more direct readouts of HR later showed that hyperthermia $\left(>41{ }^{\circ} \mathrm{C}\right)$ does inhibit HR, in human and mouse cells [150]. In particular, heat delays formation of IRIF by key HR proteins RAD51 and BRCA2 and inhibits HRmediated gene targeting in mouse ES cells, possibly by inducing robust but temporary degradation of BRCA2 [150-152]. This hyperthermia-induced HR deficiency is enhanced by concomitant inhibition of HSP90 and can be used to sensitize cells to inhibitors of Poly (ADP-ribose) polymerase (PARP) $[150,153]$. Heat $\left(>41{ }^{\circ} \mathrm{C}\right)$ also inactivates RPA [154], reduces the levels of nuclear MRE11 
protein and disrupts the interactions between the members of the MRN complex [155-158], which may be of consequence for initiation and progression of HR [159]. Interestingly, a reduction of BRCA1 protein levels is also seen upon heat exposure $\left(42-44{ }^{\circ} \mathrm{C}\right)[135,160]$ and BRCA1 seems to protect cells from effects of heat, such that overexpression of wild-type BRCA1 in cells decreases their heat sensitivity and mutant BRCA1 cells are more sensitive to treatment at $42{ }^{\circ} \mathrm{C}$ [160]. Additionally, the temperature of $42.5{ }^{\circ} \mathrm{C}$ may inhibit the recruitment of RAD51 to stalled replication forks [161].

Further evidence of targeting HR by hyperthermia can be found in studies of hyperthermic sensitization to various chemotherapeutic drugs. Nucleoside analogue gemcitabine is incorporated into the DNA during replication, leading to collapse of replication forks and generation of DSBs that are mostly restored by HR $[148,161,162]$. Hyperthermia $\left(42.5^{\circ} \mathrm{C}\right)$ inhibits the recruitment of RAD51 and impairs HR repair at stalled replication forks, thereby sensitizing cells to gemcitabine [161] (Table 1). HR is also involved in repair of SSBs and DSBs induced by ionizing radiation and other types of DNA damage, including cross-links induced by platinum compounds or mitomycin $\mathrm{C}$, and hyperthermia can sensitize cells to all these agents (Table 1). However, multiple other pathways participate in repair of these lesions (Table 1), obscuring the importance of $\mathrm{HR}$ in the process.

\section{Clinical perspective}

The potential of hyperthermia to sensitize (cancer) cells to DNA damaging agents (Table 1) has been obvious for many decades. However, clear clinical benefits could only be demonstrated much later, perhaps due to technical challenges related to the development of reliable hyperthermia applicators, treatment planning and adequate dosimetry [163-165]. The effectivity of hyperthermia combined with radiation has been demonstrated in several randomized phase II/III trials for melanoma, cervix, breast, head and neck cancer, showing a significant enhancement in radiation effectivity without a significant increase in toxicity [166-170]. Also, the combination of hyperthermia and cisplatin or similar agents has been tested in a number of phase II and some phase III trials. Hyperthermia enhanced the effectiveness of mitomycin C in phase III trials for bladder cancer $[171,172]$ and of etoposide, ifosfamide and doxorubicin for soft tissue sarcomas [173]. A review on Hyperthermic IntraPEritoneal Chemotherapy (HIPEC) treatment for ovarian cancer showed no increase of toxicity due to hyperthermia [174]. Reviews summarizing about 30 randomized hyperthermia trials are given in [175-177]. An overview of the clinical effectivity and toxicity of trimodality treatment schedules comprising hyperthermia, radiation and cisplatin or oxaliplatin was given by [178], listing 13 nonrandomized phase I/II trials for breast, head and neck, cervix and oesophagus cancer. Results showed that this form of trimodality treatment is feasible and effective with only moderate toxicity. Also, multiple studies in recurrent cervical cancer show that hyperthermia enhanced the uptake and cytotoxicity of cisplatin without additional side effects [19, 179-181]. Summarizing, hyperthermia has shown very significant enhancement of the effectivity of both radiotherapy and chemotherapy without increasing toxicity in various multi-modality settings. The multitude of drug combinations and treatment modalities that show positive effects in combination with hyperthermia seems to reflect the multitude of DNA repair and other pathways that are affected by heat.

\section{Conclusions}

Hyperthermia has been subject of investigations for nearly half a century, yet its numerous effects on cells and tissues still remain unclear. In particular, it is not well known how heat interacts with DNA repair pathways, which is highly relevant in clinical cancer treatment. It is apparent from studies reviewed here that in the early years of hyperthermia research many of major effects of hyperthermia on cells were observed, but mechanistic insight was lacking due to limited understanding of cellular pathways, including DDR. As this understanding deepened and new

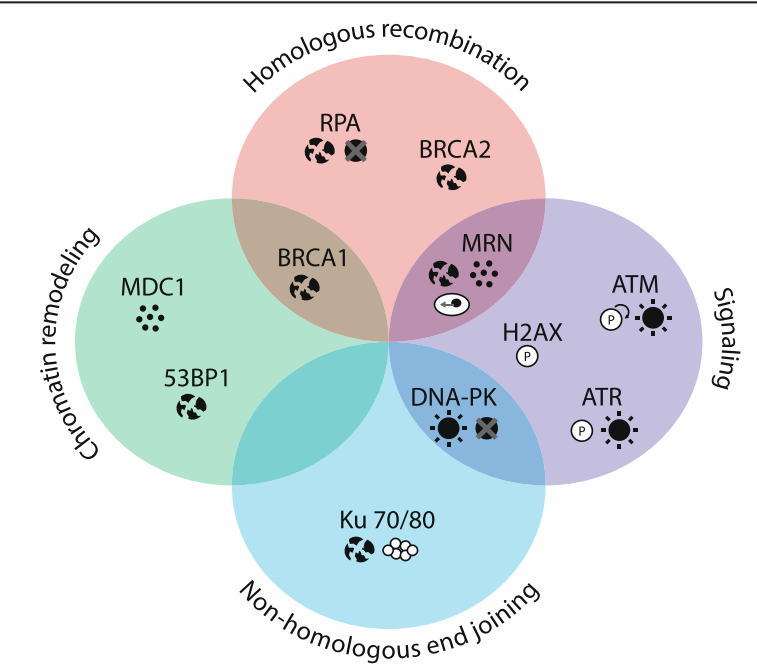
* Degradation/depletion
(๑) Autophosphorylation
$\$ 8$ Aggregation
$\because$ Formation of IRIF-like foci
(D) Phosphorylation
Inactivation/inhibition of activity
Activation/ increased activity
Delocalization from the nucleus

Fig. 1 Schematic overview of the effects of hyperthermia on DNA repair factors BRCA1 [135, 160], BRCA2 [150], MRN complex [30, 37, 155-158], RPA [71, 154], ATM [35, 36, 43], ATR [67, 68], DNA-PK $[43,133,135], \mathrm{Ku} 70 / 80[131,132,134,135], \operatorname{H2AX}[31,37,38]$, MDC1 [35] and 53BP1 [135] 
molecular biology tools became available in the 1990s and 2000s, the search for proteins and pathways targeted by hyperthermia intensified. Major contributions were made by studies that analysed hyperthermic sensitization in DNA repair-deficient cells. However, results of these studies were generally interpreted under assumption that one major pathway is responsible for the effects of heat on DNA repair, leading to multiple conflicting hypotheses. We now only begin to see how many facets of DDR are disturbed, including direct effects on major DNA repair factors (Fig. 1), damage signaling, checkpoints, cell cycle progression and apoptosis.

Although difficult to study, these effects are highly beneficial in clinical practice. By disturbing multiple DNA repair pathways, hyperthermia sensitizes cells to a broad range of DNA-damaging agents. Recent clinical trials clearly demonstrated the benefits and safety of treatments involving hyperthermia. Although much remains to be discovered, hyperthermia is no longer the black box it once was and it is bound, in the near future, to take more central stage in clinical cancer treatment.

\section{Competing interests}

Authors declare that they have no competing interests.

\section{Authors' contributions}

PMK devised the concept, ALO, LEMV, JC, NAPF and PMK wrote the manuscript. All authors read and approved the final manuscript.

\section{Acknowledgements}

This work was supported by the Dutch Cancer Society (grants \# UVA 2008-4019, \# UVA 2012-5540 and UVA 2011-4962), NWO Medium grant and the Maurits en Anna de Kock foundation.

\section{Author details \\ 'Laboratory for Experimental Oncology and Radiobiology (LEXOR), Center for Experimental and Molecular Medicine, Academic Medical Center, University of Amsterdam, 1105 AZ Amsterdam, The Netherlands. ${ }^{2}$ Van Leeuwenhoek Centre for Advanced Microscopy (LCAM)-AMC, Department of Cell Biology and Histology, Academic Medical Center, University of Amsterdam, Meibergdreef 15, 1105 AZ Amsterdam, The Netherlands. ${ }^{3}$ Department of Radiotherapy, Academic Medical Center, University of Amsterdam, 1105 AZ Amsterdam, The Netherlands.}

Received: 8 May 2015 Accepted: 13 July 2015

Published online: 07 August 2015

\section{References}

1. Engin K. Biological rationale and clinical experience with hyperthermia. Control Clin Trials. 1996;17:316-42.

2. Luchetti F, Canonico B, Della Felice M, Burattini S, Battistelli M, Papa S, et al. Hyperthermia triggers apoptosis and affects cell adhesiveness in human neuroblastoma cells. Histol Histopathol. 2003;18:1041-52.

3. Lepock JR. Role of nuclear protein denaturation and aggregation in thermal radiosensitization. Int J Hyperthermia. 2004;20:115-30.

4. Vertrees RA, Das GC, Coscio AM, Xie J, Zwischenberger JB, Boor PJ. A mechanism of hyperthermia-induced apoptosis in ras-transformed lung cells. Mol Carcinog. 2005;44:111-21.

5. Roti Roti JL. Cellular responses to hyperthermia (40-46 degrees C): cell killing and molecular events. Int J Hyperthermia. 2008;24:3-15.

6. Braun J, Hahn GM. Enhanced cell killing by bleomycin and 43 degrees hyperthermia and the inhibition of recovery from potentially lethal damage. Cancer Res. 1975;35:2921-7.

7. Hill SA, Denekamp J. The response of six mouse tumours to combined heat and X rays: implications for therapy. Br J Radiol. 1979;52:209-18.
8. Henle KJ. Sensitization to hyperthermia below 43 degrees $C$ induced in Chinese hamster ovary cells by step-down heating. J Natl Cancer Inst. 1980;64:1479-83.

9. Stewart FA, Denekamp J. Fractionation studies with combined $\mathrm{X}$ rays and hyperthermia in vivo. Br J Radiol. 1980;53:346-56.

10. Mizuno $S$, Amagai $M$, Ishida A. Synergistic cell killing by antitumor agents and hyperthermia in cultured cells. Gan. 1980;71:471-8.

11. Ishida A, Mizuno S. Synergistic enhancement of bleomycin cytotoxicity toward tumor cells in culture by a combination of ethanol and moderate hyperthermia. Gan. 1981;72:455-8.

12. Herman TS, Henle KJ, Nagle WA, Moss AJ, Monson TP. Effect of step-down heating on the cytotoxicity of adriamycin, bleomycin, and cisdiamminedichloroplatinum. Cancer Res. 1984;44:1823-6.

13. Hazan G, Lurie H, Yerushalmi A. Sensitization of combined cis-platinum and cyclophosphamide by local hyperthermia in mice bearing the Lewis lung carcinoma. Oncology. 1984;41:68-9.

14. Warters RL, Henle KJ. DNA degradation in chinese hamster ovary cells after exposure to hyperthermia. Cancer Res. 1982;42:4427-32.

15. Anai H, Maehara Y, Sugimachi K. In situ nick translation method reveals DNA strand scission in HeLa cells following heat treatment. Cancer Lett. 1988:40:33-8.

16. Wong RS, Dynlacht JR, Cedervall B, Dewey WC. Analysis by pulsed-field gel electrophoresis of DNA double-strand breaks induced by heat and/or X-irradiation in bulk and replicating DNA of $\mathrm{CHO}$ cells. Int J Radiat Biol. 1995;68:141-52.

17. Van der Zee J, González GD. The Dutch Deep Hyperthermia Trial: results in cervical cancer. Int J Hyperthermia. 2002;18:1-12.

18. Franckena M, Lutgens LC, Koper PC, Kleynen CE, van der Steen-Banasik EM Jobsen JJ, et al. Radiotherapy and hyperthermia for treatment of primary locally advanced cervix cancer: results in 378 patients. Int J Radiat Oncol Biol Phys. 2009;73:242-50.

19. Heijkoop ST, van Doorn HC, Stalpers LJA, Boere IA, van der Velden J, Franckena $\mathrm{M}$, et al. Results of concurrent chemotherapy and hyperthermia in patients with recurrent cervical cancer after previous chemoradiation. Int J Hyperthermia. 2014;30:6-10.

20. Al-Ahmady ZS, Al-Jamal WT, Bossche JV, Bui TT, Drake AF, Mason AJ, et al. Lipid-peptide vesicle nanoscale hybrids for triggered drug release by mild hyperthermia in vitro and in vivo. ACS Nano. 2012;6:9335-46.

21. Yarmolenko PS, Moon EJ, Landon C, Manzoor A, Hochman DW, Viglianti BL, et al. Thresholds for thermal damage to normal tissues: an update. Int J Hyperthermia. 2011;27:320-43.

22. Jorritsma JB, Konings AW. The occurrence of DNA strand breaks after hyperthermic treatments of mammalian cells with and without radiation. Radiat Res. 1984;98:198-208.

23. Jorritsma JB, Konings AW. DNA lesions in hyperthermic cell killing: effects of thermotolerance, procaine, and erythritol. Radiat Res. 1986;106:89-97.

24. Dikomey E, Franzke J. Effect of heat on induction and repair of DNA strand breaks in X-irradiated CHO cells. Int J Radiat Biol. 1992;61:221-33.

25. Wong RS, Kapp LN, Krishnaswamy G, Dewey WC. Critical steps for induction of chromosomal aberrations in $\mathrm{CHO}$ cells heated in $\mathrm{S}$ phase. Radiat Res. 1993;133:52-9

26. Warters RL, Brizgys LM. Apurinic site induction in the DNA of cells heated at hyperthermic temperatures. J Cell Physiol. 1987;133:144-50.

27. Dahm-Daphi J, Brammer I, Dikomey E. Heat effects on the repair of DNA double-strand breaks in CHO cells. Int J Radiat Biol. 1997;72:171-9.

28. Kampinga HH, Hiemstra YS, Konings AW, Dikomey E. Correlation between slowly repairable double-strand breaks and thermal radiosensitization in the human HeLa S3 cell line. Int J Radiat Biol. 1997;72:293-301.

29. Takahashi A, Matsumoto H, Nagayama K, Kitano M, Hirose S, Tanaka H, et al. Evidence for the involvement of double-strand breaks in heat-induced cell killing. Cancer Res. 2004;64:8839-45.

30. Takahashi A, Mori E, Ohnishi T. Phospho-Nbs1 and Mre11 proteins which recognize DSBs co-localize with $\mathrm{YH} 2 \mathrm{AX}$ in the nucleus after heat treatment. Annals of Cancer Research and Therapy. 2007;15:50-3.

31. Takahashi A, Mori E, Somakos Gl, Ohnishi K, Ohnishi T. Heat induces $ү \mathrm{H} 2 \mathrm{AX}$ foci formation in mammalian cells. Mutat Res. 2008;656:88-92.

32. Rogakou EP, Pilch DR, Orr AH, Ivanova VS, Bonner WM. DNA double-stranded breaks induce histone H2AX phosphorylation on serine 139. J Biol Chem. 1998;273:5858-68.

33. Rogakou EP, Boon C, Redon C, Bonner WM. Megabase chromatin domains involved in DNA double-strand breaks in vivo. J Cell Biol. 1999;146:905-16. 
34. Li GC, Mivechi NF, Weitzel G. Heat shock proteins, thermotolerance, and their relevance to clinical hyperthermia. Int J Hyperthermia. 1995;11:459-88

35. Hunt CR, Pandita RK, Laszlo A, Higashikubo R, Agarwal M, Kitamura T, et al. Hyperthermia activates a subset of ataxia-telangiectasia mutated effectors independent of DNA strand breaks and heat shock protein 70 status. Cancer Res. 2007;67:3010-7.

36. Takahashi A, Mori E, Su X, Nakagawa Y, Okamoto N, Uemura H, et al. ATM is the predominant kinase involved in the phosphorylation of histone $\mathrm{H} 2 \mathrm{AX}$ after heating. J Radiat Res. 2010;51:417-22.

37. Takahashi A, Mori E, Ohnishi T. The Foci of DNA Double Strand Break-recognition Proteins Localize with $\mathrm{YH} 2 \mathrm{AX}$ after Heat Treatment. J Radiat Res. 2010;51:91-5.

38. Laszlo A, Fleischer I. The heat-induced gamma-H2AX response does not play a role in hyperthermic cell killing. Int J Hyperthermia. 2009;25:199-209.

39. Soutoglou E, Misteli T. Activation of the cellular DNA damage response in the absence of DNA lesions. Science. 2008;320:1507-10.

40. Bencokova Z, Kaufmann MR, Pires IM, Lecane PS, Giaccia AJ, Hammond EM. ATM activation and signaling under hypoxic conditions. Mol Cell Biol. 2009;29:526-37.

41. Pospelova TV, Demidenko ZN, Bukreeva El, Pospelov VA, Gudkov AV, Blagosklonny MV. Pseudo-DNA damage response in senescent cells. Cell Cycle. 2009;8:4112-8.

42. Wang L, Dai W, Lu L. Osmotic stress-induced phosphorylation of H2AX by polo-like kinase 3 affects cell cycle progression in human corneal epithelial cells. J Biol Chem. 2014;289:29827-35.

43. Velichko AK, Petrova NV, Kantidze OL, Razin SV. Dual effect of heat shock on DNA replication and genome integrity. Mol Biol Cell. 2012;23:3450-60.

44. VanderWaal RP, Griffith CL, Wright WD, Borrelli MJ, Roti JL. Delaying S-phase progression rescues cells from heat-induced S-phase hypertoxicity. J Cell Physiol. 2001;187:236-43.

45. Lukas C, Savic V, Bekker-Jensen S, Doil C, Neumann B, Pedersen RS, et al. 53BP1 nuclear bodies form around DNA lesions generated by mitotic transmission of chromosomes under replication stress. Nat Cell Biol. 2011;13:243-53.

46. Kampinga HH, Laszlo A. DNA double strand breaks do not play a role in heat-induced cell killing. Cancer Res. 2005;65:10632-3. author reply 10633.

47. Shaltiel IA, Krenning L, Bruinsma W, Medema RH. The same, only different - DNA damage checkpoints and their reversal throughout the cell cycle. J Cell Sci. 2015;128:607-20.

48. Zou L, Elledge SJ. Sensing DNA damage through ATRIP recognition of RPA-ssDNA complexes. Science. 2003;300:1542-8.

49. Lee J-H, Paull TT. Direct activation of the ATM protein kinase by the Mre11/ Rad50/Nbs1 complex. Science. 2004;304:93-6.

50. Matsuoka S, Huang M, Elledge SJ. Linkage of ATM to cell cycle regulation by the Chk2 protein kinase. Science. 1998;282:1893-7.

51. Jazayeri A, Falck J, Lukas C, Bartek J, Smith GCM, Lukas J, et al. ATM- and cell cycle-dependent regulation of ATR in response to DNA double-strand breaks. Nat Cell Biol. 2006;8:37-45.

52. Shiotani B, Zou L. Single-stranded DNA orchestrates an ATM-to-ATR switch at DNA breaks. Mol Cell. 2009;33:547-58.

53. Westra A, Dewey WC. Variation in sensitivity to heat shock during the cell-cycle of Chinese hamster cells in vitro. Int. J. Radiat. Biol. Relat. Stud. Phys. Chem Med. 1971;19:467-77.

54. Hildebrandt B, Wust P, Ahlers O, Dieing A, Sreenivasa G, Kerner T, et al. The cellular and molecular basis of hyperthermia. Crit Rev Oncol Hematol. 2002:43:33-56

55. Mackey MA, Morgan WF, Dewey WC. Nuclear fragmentation and premature chromosome condensation induced by heat shock in S-phase Chinese hamster ovary cells. Cancer Res. 1988;48:6478-83.

56. Deorukhakar W, Anjaria KB, Rao BS. Modification of radiation-induced damage by hyperthermia-role of repair processes. Int J Hyperthermia. 1993:9:803-10.

57. Vidair CA, Dewey WC. Two distinct modes of hyperthermic cell death. Radiat Res. 1988;116:157-71.

58. Coss RA, Dewey WC, Bamburg JR. Effects of hyperthermia on dividing Chinese hamster ovary cells and on microtubules in vitro. Cancer Res. 1982;42:1059-71.

59. Dewey WC. Failla memorial lecture. The search for critical cellular targets damaged by heat. Radiat. Res. 1989;120:191-204.
60. Sisken JE, Morasca L, Kibby S. Effects of temperature on the kinetics of the mitotic cycle of mammalian cells in culture. Exp Cell Res. 1965;39:103-16

61. Higashikubo R, Holland JM, Roti Roti JL. Comparative effects of caffeine on radiation- and heat-induced alterations in cell cycle progression. Radiat Res. 1989;119:246-60

62. Nishita M, Inoue S, Tsuda M, Tateda C, Miyashita T. Nuclear translocation and increased expression of Bax and disturbance in cell cycle progression without prominent apoptosis induced by hyperthermia. Exp Cell Res. 1998;244:357-66

63. Lim C-U, Zhang Y, Fox MH. Cell cycle dependent apoptosis and cell cycle blocks induced by hyperthermia in HL-60 cells. Int J Hyperthermia. 2006:22:77-91.

64. Miyakoda M, Suzuki K, Kodama S, Watanabe M. Activation of ATM and phosphorylation of p53 by heat shock. Oncogene. 2002;21:1090-6.

65. Jung HJ, Seo YR. Protective effects of thioredoxin-mediated p53 activation in response to mild hyperthermia. Oncol Rep. 2012;27:650-6.

66. Laszlo A, Fleischer I. Heat-induced perturbations of DNA damage signaling pathways are modulated by molecular chaperones. Cancer Res. 2009;69:2042-9.

67. Tuul M, Kitao H, limori M, Matsuoka K, Kiyonari S, Saeki H, et al. Rad9, Rad17, TopBP1 and claspin play essential roles in heat-induced activation of ATR kinase and heat tolerance. PLoS One. 2013;8, e55361.

68. Furusawa Y, lizumi T, Fujiwara Y, Zhao Q-L, Tabuchi Y, Nomura T, et al. Inhibition of checkpoint kinase 1 abrogates G2/M checkpoint activation and promotes apoptosis under heat stress. Apoptosis. 2012;17:102-12.

69. Yan S, Michael WM. TopBP1 and DNA polymerase alpha-mediated recruitment of the 9-1-1 complex to stalled replication forks: implications for a replication restart-based mechanism for ATR checkpoint activation. Cell Cycle. 2009;8:2877-84.

70. Warters RL, Stone OL. The effects of hyperthermia on DNA replication in HeLa cells. Radiat Res. 1983;93:71-84.

71. Wang Y, Guan J, Wang H, Wang Y, Leeper D, lliakis G. Regulation of dna replication after heat shock by replication protein a-nucleolin interactions. J Biol Chem. 2001;276:20579-88.

72. Niakis G, Krieg T, Guan J, Wang Y, Leeper D. Evidence for an S-phase checkpoint regulating DNA replication after heat shock: a review. Int $J$ Hyperthermia. 2004;20:240-9.

73. Giovinazzi S, Bellapu D, Morozov VM, Ishov AM. Targeting mitotic exit with hyperthermia or APC/C inhibition to increase paclitaxel efficacy. Cell Cycle. 2013;12:2598-607.

74. Mackey MA, lanzini F. Enhancement of radiation-induced mitotic catastrophe by moderate hyperthermia. Int J Radiat Biol. 2000;76:273-80.

75. Urano M, Douple EB. Biology of Thermal Potentiation of Radiotherapy. 1989.

76. Terasawa M, Shinohara A, Shinohara M. Canonical non-homologous end joining in mitosis induces genome instability and is suppressed by Mphase-specific phosphorylation of XRCC4. PLoS Genet. 2014;10, e1004563.

77. Iliakis GE, Pantelias GE. Effects of Hyperthermia on Chromatin Condensation and Nucleoli Disintegration as Visualized by Induction of Premature Chromosome Condensation in Interphase Mammalian Cells. Cancer Res. 1989:49:1254-60

78. Dianov GL, Hübscher U. Mammalian base excision repair: the forgotten archangel. Nucleic Acids Res. 2013;41:3483-90.

79. Kampinga HH, Dikomey E. Hyperthermic radiosensitization: mode of action and clinical relevance. Int J Radiat Biol. 2001;77:399-408.

80. Kampinga HH, Dynlacht JR, Dikomey E. Mechanism of radiosensitization by hyperthermia $\left(43^{\circ} \mathrm{C}\right)$ as derived from studies with DNA repair defective mutant cell lines. Int J Hyperthermia. 2004;20:131-9.

81. Warters RL, Roti Roti JL. Excision of X-ray-induced thymine damage in chromatin from heated cells. Radiat Res. 1979:79:113-21.

82. Spiro IJ, Denman DL, Dewey WC. Effect of Hyperthermia on CHO DNA Polymerases $\alpha$ and $\beta$. Radiat Res. 1982:89:134-49.

83. Mivechi NF, Dewey WC. DNA polymerase alpha and beta activities during the cell cycle and their role in heat radiosensitization in Chinese hamster ovary cells. Radiat Res. 1985;103:337-50.

84. Dikomey E, Becker W, Wielckens K. Reduction of DNA-polymerase beta activity of $\mathrm{CHO}$ cells by single and combined heat treatments. Int. J. Radiat Biol. Relat. Stud. Phys. Chem Med. 1987;52:775-85.

85. Raaphorst GP, Feeley MM, Chu GL, Dewey WC. A comparison of the enhancement of radiation sensitivity and DNA polymerase inactivation by hyperthermia in human glioma cells. Radiat Res. 1993;134:331-6. 
86. Dikomey $\mathrm{E}$, Jung $\mathrm{H}$. Correlation between thermal radiosensitization and heat-induced loss of DNA polymerase beta activity in CHO cells. Int J Radiat Biol. 1993;63:215-21.

87. Jorritsma JB, Burgman $\mathrm{P}$, Kampinga $\mathrm{HH}$, Konings AW. DNA polymerase activity in heat killing and hyperthermic radiosensitization of mammalian cells as observed after fractionated heat treatments. Radiat Res. 1986;105:307-19.

88. Fang $Q$, Inanc $B$, Schamus $S$, Wang $X-H$, Wei $L$, Brown AR, et al. HSP90 regulates DNA repair via the interaction between XRCC1 and DNA polymerase $\beta$. Nat Commun. 2014;5:5513.

89. Fantini D, Moritz E, Auvré F, Amouroux R, Campalans A, Epe B, et al. Rapid inactivation and proteasome-mediated degradation of OGG1 contribute to the synergistic effect of hyperthermia on genotoxic treatments. DNA Repair. 2013;12:227-37.

90. Batuello CN, Kelley MR, Dynlacht JR. Role of Ape1 and Base Excision Repair in the Radiation Response and Heat-radiosensitization of HeLa Cells. Anticancer Res. 2009;29:1319-25.

91. Chen DS, Olkowski ZL. Biological Responses of Human Apurinic Endonuclease to Radiation-Induced DNA Damage. Ann N Y Acad Sci. 1994;726:306-8.

92. Marteijn JA, Lans H, Vermeulen W, Hoeijmakers JHJ. Understanding nucleotide excision repair and its roles in cancer and ageing. Nat Rev Mol Cell Biol. 2014;15:465-81.

93. Schmidt-Rose T, Pollet D, Will K, Bergemann J, Wittern KP. Analysis of UV-B-induced DNA damage and its repair in heat-shocked skin cells. J Photochem Photobiol B. 1999;53:144-52.

94. Räschle M, Knipscheer P, Knipsheer P, Enoiu M, Angelov T, Sun J, et al. Mechanism of replication-coupled DNA interstrand crosslink repair. Cell. 2008;134:969-80.

95. Enoiu M, Jiricny J, Schärer OD. Repair of cisplatin-induced DNA interstrand crosslinks by a replication-independent pathway involving transcriptioncoupled repair and translesion synthesis. Nucleic Acids Res. 2012;40:8953-64.

96. Zhu G, Myint M, Ang WH, Song L, Lippard SJ. Monofunctional platinum-DNA adducts are strong inhibitors of transcription and substrates for nucleotide excision repair in live mammalian cells. Cancer Res. 2012;72:790-800.

97. Wallner KE, DeGregorio MW, Li GC. Hyperthermic potentiation of cis-diamminedichloroplatinum(II) cytotoxicity in Chinese hamster ovary cells resistant to the drug. Cancer Res. 1986;46:6242-5.

98. Herman TS, Teicher BA, Cathcart KNS, Kaufmann ME, Lee JB, Lee M-H. Effect of hyperthermia on cis-diamminedichloroplatinum (II)(rhodamine 123) 2 [tetrachloroplatinum (II)] in a human squamous cell carcinoma line and a cis-diamminedichloroplatinum (II)-resistant subline. Cancer Res. 1988;48:5101-5.

99. Hettinga J, Konings A, Kampinga HH. Reduction of cellular cisplatin resistance by hyperthermia-a review. Int J Hyperthermia. 1997;13:439-57.

100. Bergs JWJ, Haveman J, Ten Cate R, Medema JP, Franken NAP, Van Bree C. Effect of $41 \mathrm{C}$ and $43 \mathrm{C}$ on cisplatin radiosensitization in two human carcinoma cell lines with different sensitivities for cisplatin. Oncol Rep. 2007;18:219-26.

101. Raaphorst GP, Yang DP. The evaluation of thermal cisplatin sensitization in normal and XP human cells using mild hyperthermia at 40 and 41 degrees C. Anticancer Res. 2005;25:2649-53.

102. Muenyi CS, States VA, Masters JH, Fan TW, Helm CW, States JC. Sodium arsenite and hyperthermia modulate cisplatin-DNA damage responses and enhance platinum accumulation in murine metastatic ovarian cancer xenograft after hyperthermic intraperitoneal chemotherapy (HIPEC). J Ovarian Res. 2011:4:9.

103. Nadin SB, Cuello-Carrión FD, Sottile ML, Ciocca DR, Vargas-Roig LM. Effects of hyperthermia on Hsp27 (HSPB1), Hsp72 (HSPA1A) and DNA repair proteins hMLH1 and hMSH2 in human colorectal cancer hMLH1-deficient and hMLH1-proficient cell lines. Int J Hyperthermia. 2012;28:191-201.

104. De Laat WL, Jaspers NG, Hoeijmakers JH. Molecular mechanism of nucleotide excision repair. Genes Dev. 1999;13:768-85.

105. Fu D, Calvo JA, Samson LD. Balancing repair and tolerance of DNA damage caused by alkylating agents. Nat Rev Cancer. 2012;12:104-20.

106. Guillotin D, Martin SA. Exploiting DNA mismatch repair deficiency as a therapeutic strategy. Exp Cell Res. 2014;329:110-5.

107. Swift LH, Golsteyn RM. Genotoxic anti-cancer agents and their relationship to DNA damage, mitosis, and checkpoint adaptation in proliferating cancer cells. Int J Mol Sci. 2014;15:3403-31.
108. Kondo N, Takahashi A, Ono K, Ohnishi T. DNA damage induced by alkylating agents and repair pathways. J Nucleic Acids. 2010;2010:543531.

109. Lieber MR. The mechanism of double-strand DNA break repair by the nonhomologous DNA end-joining pathway. Annu Rev Biochem. 2010;79:181-211.

110. Ochi T, Blackford AN, Coates J, Jhujh S, Mehmood S, Tamura N, et al. DNA repair. PAXX, a paralog of XRCC4 and XLF, interacts with Ku to promote DNA double-strand break repair. Science. 2015:347:185-8.

111. Soni A, Siemann M, Grabos M, Murmann T, Pantelias GE, lliakis G. Requirement for Parp-1 and DNA ligases 1 or 3 but not of $\mathrm{Xrcc} 1$ in chromosomal translocation formation by backup end joining. Nucleic Acids Res. 2014;42:6380-92.

112. Simsek D, Jasin M. Alternative end-joining is suppressed by the canonical NHEJ component Xrcc4-ligase IV during chromosomal translocation formation. Nat Struct Mol Biol. 2010;17:410-6.

113. Boboila C, Jankovic M, Yan CT, Wang JH, Wesemann DR, Zhang T, et al. Alternative end-joining catalyzes robust lgH locus deletions and translocations in the combined absence of ligase 4 and Ku70. Proc Natl Acad Sci U S A. 2010;107:3034-9.

114. Palzer RJ, Heidelberger C. Influence of drugs and synchrony on the hyperthermic killing of HeLa cells. Cancer Res. 1973;33:422-7.

115. Bhuyan BK, Day KJ, Edgerton CE, Ogunbase O. Sensitivity of different cell lines and of different phases in the cell cycle to hyperthermia. Cancer Res. 1977;37:3780-4

116. Leith JT, Miller RC, Gerner EW, Boone ML. Hyperthermic potentiation: biological aspects and applications to radiation therapy. Cancer. 1977;39:766-79.

117. Iliakis G, Seaner R, Okayasu R. Effects of hyperthermia on the repair of radiation-induced DNA single- and double-strand breaks in DNA double-strand break repair-deficient and repair-proficient cell lines. Int J Hyperthermia. 1990;6:813-33.

118. Iliakis G, Seaner R. A DNA double-strand break repair-deficient mutant of $\mathrm{CHO}$ cells shows reduced radiosensitization after exposure to hyperthermic temperatures in the plateau phase of growth. Int J Hyperthermia. 1990;6:801-12.

119. Taccioli GE, Gottlieb TM, Blunt T, Priestley A, Demengeot J, Mizuta R, et al. Ku80: product of the XRCC5 gene and its role in DNA repair and V(D)J recombination. Science. 1994;265:1442-5.

120. Smider V, Rathmell WK, Lieber MR, Chu G. Restoration of X-ray resistance and V (D) J recombination in mutant cells by Ku cDNA. Science. 1994;266:288-91.

121. Getts RC, Stamato TD. Absence of a Ku-like DNA end binding activity in the xrs double-strand DNA repair-deficient mutant. J Biol Chem. 1994;269:15981-4.

122. Kampinga HH, Kanon B, Konings AW, Stackhouse MA, Bedford JS. Thermal radiosensitization in heat- and radiation-sensitive mutants of $\mathrm{CHO}$ cells. Int J Radiat Biol. 1993;64:225-30

123. Raaphorst GP, Thakar M, Ng CE. Thermal radiosensitization in two pairs of $\mathrm{CHO}$ wild-type and radiation-sensitive mutant cell lines. Int J Hyperthermia. 1993:9:383-91.

124. Komatsu K, Kubota N, Gallo M, Okumura Y, Lieber MR. The scid factor on human chromosome 8 restores $V(D) J$ recombination in addition to double-strand break repair. Cancer Res. 1995;55:1774-9.

125. Woudstra EC, Konings AW, Jeggo PA, Kampinga HH. Role of DNA-PK subunits in radiosensitization by hyperthermia. Radiat Res. 1999;152:214-8.

126. Dynlacht JR, Bittner ME, Bethel JA, Beck BD. The non-homologous end-joining pathway is not involved in the radiosensitization of mammalian cells by heat shock. J Cell Physiol. 2003;196:557-64.

127. Tomita M, Suzuki N, Matsumoto Y, Hirano K, Umeda N, Sakai K. Sensitization by wortmannin of heat- or X-ray induced cell death in cultured Chinese hamster V79 cells. J Radiat Res. 2000:41:93-102.

128. Okazawa S, Furusawa Y, Kariya A, Hassan MA, Arai M, Hayashi R, et al. Inactivation of DNA-dependent protein kinase promotes heat-induced apoptosis independently of heat-shock protein induction in human cancer cell lines. PLoS One. 2013;8, e58325.

129. Iliakis $G, W u$ W, Wang M. DNA double strand break repair inhibition as a cause of heat radiosensitization: re-evaluation considering backup pathways of NHEJ. Int J Hyperthermia. 2008;24:17-29.

130. Windhofer F, Wu W, Wang M, Singh SK, Saha J, Rosidi B, et al. Marked dependence on growth state of backup pathways of NHEJ. Int J Radiat Oncol Biol Phys. 2007;68:1462-70.

131. Burgman P, Ouyang H, Peterson S, Chen DJ, Li GC. Heat inactivation of Ku autoantigen: possible role in hyperthermic radiosensitization. Cancer Res. 1997;57:2847-50 
132. Matsumoto Y, Suzuki N, Sakai K, Morimatsu A, Hirano K, Murofushi H. A possible mechanism for hyperthermic radiosensitization mediated through hyperthermic lability of Ku subunits in DNA-dependent protein kinase. Biochem Biophys Res Commun. 1997;234:568-72.

133. Ihara M, Suwa A, Komatsu K, Shimasaki T, Okaichi K, Hendrickson EA, et al. Heat sensitivity of double-stranded DNA-dependent protein kinase (DNA-PK) activity. Int J Radiat Biol. 1999;75:253-8.

134. Beck BD, Dynlacht JR. Heat-induced aggregation of XRCC5 (Ku80) in nontolerant and thermotolerant cells. Radiat Res. 2001;156:767-74.

135. Ihara M, Takeshita S, Okaichi K, Okumura Y, Ohnishi T. Heat exposure enhances radiosensitivity by depressing DNA-PK kinase activity during double strand break repair. Int J Hyperthermia. 2014;30:102-9.

136. Yuan S-SF, Yang Y-K, Chen H-W, Chung Y-F, Chang H-L, Su J-H. Neocarzinostatin-induced Rad51 nuclear focus formation is cell cycle regulated and aberrant in AT cells. Toxicol Appl Pharmacol. 2003;192:231-6.

137. Mladenov E, Kalev P, Anachkova B. The complexity of double-strand break ends is a factor in the repair pathway choice. Radiat Res. 2009;171:397-404

138. Adachi N, Ishino T, Ishii Y, Takeda S, Koyama H. DNA ligase IV-deficient cells are more resistant to ionizing radiation in the absence of Ku70: Implications for DNA double-strand break repair. Proc Natl Acad Sci U S A. 2001;98:12109-13.

139. Mohapatra S, Kawahara M, Khan IS, Yannone SM, Povirk LF. Restoration of G1 chemo/radioresistance and double-strand-break repair proficiency by wild-type but not endonuclease-deficient Artemis. Nucleic Acids Res. 2011;39:6500-10

140. Adachi N, Suzuki H, liizumi S, Koyama H. Hypersensitivity of nonhomologous DNA end-joining mutants to VP-16 and ICRF-193: implications for the repair of topoisomerase II-mediated DNA damage. J Biol Chem. 2003;278:35897-902

141. Kampinga $\mathrm{HH}$. Hyperthermia, thermotolerance and topoisomerase II inhibitors. Br J Cancer. 1995;72:333-8.

142. Li CJ, Averboukh L, Pardee AB. beta-Lapachone, a novel DNA topoisomerase I inhibitor with a mode of action different from camptothecin. J Biol Chem. 1993;268:22463-8.

143. Krishnan P, Bastow KF. Novel mechanisms of DNA topoisomerase II inhibition by pyranonaphthoquinone derivatives-eleutherin, a lapachone, and $\beta$ lapachone. Biochem Pharmacol. 2000;60:1367-79.

144. Park HJ, Choi EK, Choi J, Ahn K-J, Kim EJ, Ji I-M, et al. Heat-induced up-regulation of $\mathrm{NAD}(\mathrm{P}) \mathrm{H}$ :quinone oxidoreductase potentiates anticancer effects of beta-lapachone. Clin Cancer Res. 2005;11:8866-71.

145. Hori T, Kondo T, Lee H, Song CW, Park HJ. Hyperthermia enhances the effect of $\beta$-lapachone to cause $\gamma \mathrm{H} 2 \mathrm{AX}$ formations and cell death in human osteosarcoma cells. Int J Hyperthermia. 2011;27:53-62.

146. Jasin M, Rothstein R. Repair of strand breaks by homologous recombination. Cold Spring Harb Perspect Biol. 2013;5:a012740.

147. Raaphorst GP, Maude-Leblanc J, Li L. Evaluation of recombination repair pathways in thermal radiosensitization. Radiat Res. 2004;161:215-8.

148. Wachters FM, van Putten JWG, Maring JG, Zdzienicka MZ, Groen HJM, Kampinga $\mathrm{HH}$. Selective targeting of homologous DNA recombination repair by gemcitabine. Int J Radiat Oncol Biol Phys. 2003;57:553-62.

149. Yin HL, Suzuki Y, Matsumoto Y, Tomita M, Furusawa Y, Enomoto A, et al. Radiosensitization by hyperthermia in the chicken B-lymphocyte cell line DT40 and its derivatives lacking nonhomologous end joining and/or homologous recombination pathways of DNA double-strand break repair. Radiat Res. 2004;162:433-41.

150. Krawczyk PM, Eppink B, Essers J, Stap J, Rodermond H, Odijk H, et al. Mild hyperthermia inhibits homologous recombination, induces BRCA2 degradation, and sensitizes cancer cells to poly (ADP-ribose) polymerase-1 inhibition. Proc Natl Acad Sci U S A. 2011;108:9851-6.

151. Bergs JWJ, Krawczyk PM, Borovski T, ten Cate R, Rodermond HM, Stap J, et al. Inhibition of homologous recombination by hyperthermia shunts early double strand break repair to non-homologous end-joining. DNA Repair. 2012;12:38-45

152. Genet SC, Fujii Y, Maeda J, Kaneko M, Genet MD, Miyagawa K, et al. Hyperthermia inhibits homologous recombination repair and sensitizes cells to ionizing radiation in a time- and temperature-dependent manner. J Cell Physiol. 2013;228:1473-81.

153. Eppink B, Krawczyk PM, Stap J, Kanaar R. Hyperthermia-induced DNA repair deficiency suggests novel therapeutic anti-cancer strategies. Int J Hyperthermia. 2012;28:509-17.
154. Wang Y, Perrault AR, lliakis G. Replication protein A as a potential regulator of DNA replication in cells exposed to hyperthermia. Radiat Res. 1998;149:284-93.

155. Zhu WG, Seno JD, Beck BD, Dynlacht JR. Translocation of MRE11 from the nucleus to the cytoplasm as a mechanism of radiosensitization by heat. Radiat Res. 2001;156:95-102.

156. Seno JD, Dynlacht JR. Intracellular redistribution and modification of proteins of the Mre11/Rad50/Nbs1 DNA repair complex following irradiation and heat-shock. J Cell Physiol. 2004;199:157-70.

157. Xu M, Myerson RJ, Xia Y, Whitehead T, Moros EG, Straube WL, et al. The effects of 41 degrees $C$ hyperthermia on the DNA repair protein, MRE11, correlate with radiosensitization in four human tumor cell lines. Int J Hyperthermia. 2007;23:343-51.

158. Gerashchenko BI, Gooding G, Dynlacht JR. Hyperthermia alters the interaction of proteins of the Mre11 complex in irradiated cells. Cytometry A. 2010;77:940-52.

159. Tauchi H, Kobayashi J, Morishima K-I, van Gent DC, Shiraishi T, Verkaik NS, et al. Nbs1 is essential for DNA repair by homologous recombination in higher vertebrate cells. Nature. 2002;420:93-8.

160. Xian Ma Y, Fan S, Xiong J, Yuan R-Q, Meng Q, Gao M, et al. Role of BRCA1 in heat shock response. Oncogene. 2003:22:10-27.

161. Raoof M, Zhu C, Cisneros BT, Liu H, Corr SJ, Wilson L, et al. Hyperthermia inhibits recombination repair of gemcitabine-stalled replication forks. J Nat Cancer Inst. 2014;106:dju183.

162. Jones RM, Kotsantis P, Stewart GS, Groth P, Petermann E. BRCA2 and RAD51 promote double-strand break formation and cell death in response to gemcitabine. Mol Cancer Ther. 2014;13:2412-21.

163. Kok HP, Wust P, Stauffer PR, Bardati F, van Rhoon GC, Crezee J. Current state of the art of regional hyperthermia treatment planning: a review. Radiat Oncol. 2015:10:196.

164. Wust $P$, History, current status and perspectives of regional hyperthermia. Radiat Oncol. 2015 (in Press).

165. Van Rhoon $\mathrm{G}$, Why high quality hyperthermia is important, lessons to be learned (multi-institutional article). Radiat Oncol. 2015 (in Press).

166. Valdagni R, Amichetti M, Pani G. Radical radiation alone versus radical radiation plus microwave hyperthermia for N3 (TNM-UICC) neck nodes: a prospective randomized clinical trial. Int J Radiat Oncol Biol Phys. 1988;15:13-24.

167. Overgaard J, Gonzalez Gonzalez D, Hulshof MC, Arcangeli G, Dahl O, Mella $\mathrm{O}$, et al. Randomised trial of hyperthermia as adjuvant to radiotherapy for recurrent or metastatic malignant melanoma. European Society for Hyperthermic Oncology Lancet. 1995;345:540-3.

168. Vernon CC, Hand JW, Field SB, Machin D, Whaley JB, van der Zee J, et al. Radiotherapy with or without hyperthermia in the treatment of superficial localized breast cancer: results from five randomized controlled trials. International Collaborative Hyperthermia Group. Int. J. Radiat. Oncol. Biol. Phys. 1996;35:731-44.

169. Van der Zee J, González González D, van Rhoon GC, van Dijk JD, van Putten WL, Hart AA. Comparison of radiotherapy alone with radiotherapy plus hyperthermia in locally advanced pelvic tumours: a prospective, randomised, multicentre trial. Dutch Deep Hyperthermia Group Lancet. 2000;355:1119-25.

170. Jones EL, Oleson JR, Prosnitz LR, Samulski TV, Vujaskovic Z, Yu D, et al. Randomized trial of hyperthermia and radiation for superficial tumors. J Clin Oncol. 2005;23:3079-85.

171. Colombo R, Da Pozzo LF, Salonia A, Rigatti P, Leib Z, Baniel J, et al. Multicentric study comparing intravesical chemotherapy alone and with local microwave hyperthermia for prophylaxis of recurrence of superficial transitional cell carcinoma. J Clin Oncol. 2003;21:4270-6.

172. Colombo R, Salonia A, Leib Z, Pavone-Macaluso M, Engelstein D. Long-term outcomes of a randomized controlled trial comparing thermochemotherapy with mitomycin- $\mathrm{C}$ alone as adjuvant treatment for non-muscle-invasive bladder cancer (NMIBC). BJU Int. 2011;107:912-8.

173. Issels RD, Lindner LH, Verweij J, Wust $P$, Reichardt $P$, Schem B-C, et al, Neo-adjuvant chemotherapy alone or with regional hyperthermia for localised high-risk soft-tissue sarcoma: a randomised phase 3 multicentre study. Lancet Oncol. 2010;11:561-70.

174. Mulier S, Claes J-P, Dierieck V, Amiel J-O, Pahaut J-P, Marcelis L, et al. Survival benefit of adding Hyperthermic IntraPEritoneal Chemotherapy (HIPEC) at the different time-points of treatment of ovarian cancer: review of evidence. Curr Pharm Des. 2012;18:3793-803.

175. Horsman MR, Overgaard J. Hyperthermia: a potent enhancer of radiotherapy. Clin Oncol. 2007;19:418-26. 
176. Van der Zee J, Vujaskovic Z, Kondo M, Sugahara T. The Kadota Fund International Forum 2004-clinical group consensus. Int J Hyperthermia. 2008;24:111-22.

177. Ghadjar. Int. J. Hyperthermia. 2015. in press.

178. Bergs JWJ, Franken NAP, Haveman J, Geijsen ED, Crezee J, van Bree C. Hyperthermia, cisplatin and radiation trimodality treatment: a promising cancer treatment? A review from preclinical studies to clinical application. Int J Hyperthermia. 2007;23:329-41.

179. De Wit R, van der Zee J, van der Burg ME, Kruit WH, Logmans A, van Rhoon GC, et al. A phase I/II study of combined weekly systemic cisplatin and locoregional hyperthermia in patients with previously irradiated recurrent carcinoma of the uterine cervix. Br J Cancer. 1999:80:1387-91.

180. Rietbroek RC, Schilthuis MS, Bakker PJ, van Dijk JD, Postma AJ, González González D, et al. Phase II trial of weekly locoregional hyperthermia and cisplatin in patients with a previously irradiated recurrent carcinoma of the uterine cervix. Cancer. 1997;79:935-43.

181. Franckena M, De Wit R, Ansink AC, Notenboom A, Canters RAM, Fatehi D, et al. Weekly systemic cisplatin plus locoregional hyperthermia: an effective treatment for patients with recurrent cervical carcinoma in a previously irradiated area. Int J Hyperthermia. 2007;23:443-50.

182. Ko SH, Ueno T, Yoshimoto Y, Yoo JS, Abdel-Wahab Ol, Abdel-Wahab Z, et al. Optimizing a novel regional chemotherapeutic agent against melanoma: hyperthermia-induced enhancement of temozolomide cytotoxicity. Clin Cancer Res. 2006;12:289-97.

183. Pagani E, Falcinelli S, Pepponi R, Turriziani M, Caporaso P, Caporali S, et al. Combined effect of temozolomide and hyperthermia on human melanoma cell growth and O6-methylguanine-DNA methyltransferase activity. Int J Oncol. 2007:30:443-51.

184. Muller C, Calsou P, Salles B. The activity of the DNA-dependent protein kinase (DNA-PK) complex is determinant in the cellular response to nitrogen mustards. Biochimie. 2000;82:25-8.

185. Hazan G, Ben-Hur E, Yerushalmi A. Synergism between hyperthermia and cyclophosphamide in vivo: the effect of dose fractionation. Eur J Cancer. 1981;17:681-4

186. Hiramoto RN, Ghanta VK, Lilly MB. Reduction of tumor burden in a murine osteosarcoma following hyperthermia combined with cyclophosphamide. Cancer Res. 1984;44:1405-8.

187. Haas GP, Klugo RC, Hetzel FW, Barton EE, Cerny JC. The synergistic effect of hyperthermia and chemotherapy on murine transitional cell carcinoma. J Urol. 1984;132:828-33.

188. Gerad H, van Echo DA, Whitacre M, Ashman M, Helrich M, Foy J, et al. Doxorubicin, cyclophosphamide, and whole body hyperthermia for treatment of advanced soft tissue sarcoma. Cancer. 1984;53:2585-91.

189. Urano M, Kim MS, Kahn J, Kenton LA, Li ML. Effect of thermochemotherapy (combined cyclophosphamide and hyperthermia) given at various temperatures with or without glucose administration on a murine fibrosarcoma. Cancer Res. 1985;45:4162-6.

190. Wiedemann G, Roszinski S, Biersack A, Weiss C, Wagner T. Local hyperthermia enhances cyclophosphamide, ifosfamide andcisdiamminedichloroplatinum cytotoxicity on human-derived breast carcinoma and sarcoma xenografts in nude mice. J Cancer Res Clin Oncol. 1992;118:129-35.

191. Takemoto M, Kuroda M, Urano M, Nishimura Y, Kawasaki S, Kato H, et al. The effect of various chemotherapeutic agents given with mild hyperthermia on different types of tumours. Int J Hyperthermia. 2003;19:193-203.

192. Goss P, Parsons PG. The effect of hyperthermia and melphalan on survival of human fibroblast strains and melanoma cell lines. Cancer Res. 1977;37:152-6

193. Joiner MC, Steel GG, Stephens TC. Response of two mouse tumours to hyperthermia with CCNU or melphalan. Br J Cancer. 1982;45:17-26.

194. Honess DJ, Bleehen NM. Thermochemotherapy with cis-platinum, CCNU, BCNU, chlorambucil and melphalan on murine marrow and two tumours: therapeutic gain for melphalan only. Br J Radiol. 1985;58:63-72.

195. Bates DA, Mackillop WJ. The effect of hyperthermia in combination with melphalan on drug-sensitive and drug-resistant $\mathrm{CHO}$ cells in vitro. $\mathrm{Br} \mathrm{J}$ Cancer. 1990;62:183-8.

196. Laskowitz DT, Elion GB, Dewhirst MW, Griffith OW, Savina PM, Blum MR, et al. Hyperthermia-induced enhancement of melphalan activity against a melphalan-resistant human rhabdomyosarcoma xenograft. Radiat Res. 1992;129:218-23.
197. Orlandi L, Zaffaroni N, Bearzatto A, Costa A, Supino R, Vaglini M, et al. Effect of melphalan and hyperthermia on cell cycle progression and cyclin B1 expression in human melanoma cells. Cell Prolif. 1995;28:617-30.

198. Urano M, Ling CC. Thermal enhancement of melphalan and oxaliplatin cytotoxicity in vitro. Int J Hyperthermia. 2002;18:307-15.

199. Mohamed F, Marchettini P, Stuart OA, Urano M, Sugarbaker PH. Thermal enhancement of new chemotherapeutic agents at moderate hyperthermia. Ann Surg Oncol. 2003;10:463-8.

200. Teicher BA, Kowal CD, Kennedy KA, Sartorelli AC. Enhancement by hyperthermia of the in vitro cytotoxicity of mitomycin $C$ toward hypoxic tumor cells. Cancer Res. 1981;41:1096-9.

201. Wallner KE, Li GC. Effect of drug exposure duration and sequencing on hyperthermic potentiation of mitomycin- $C$ and cisplatin. Cancer Res. 1987:47:493-5.

202. Wallner KE, Banda M, Li GC. Hyperthermic enhancement of cell killing by mitomycin C in mitomycin C-resistant Chinese hamster ovary cells. Cancer Res. 1987:47:1308-12.

203. Van der Heijden AG, Jansen CFJ, Verhaegh G, O'donnell MA, Schalken JA, Witjes JA. The effect of hyperthermia on mitomycin-C induced cytotoxicity in four human bladder cancer cell lines. Eur Urol. 2004;46:670-4.

204. Raaphorst GP, Li LF, Yang DP, LeBlanc J-M. Cisplatin sensitization by concurrent mild hyperthermia in parental and mutant cell lines deficient in homologous recombination and non-homologous end joining repair. Oncol Rep. 2005;14:281-5.

205. Haveman J, Bergs JWJ, Franken NAP, van Bree C, Stalpers LJA. Effect of hyperthermia on uptake and cytotoxicity of cisplatin in cultured murine mammary carcinoma cells. Oncol Rep. 2005;14:561-7.

206. Eichholtz-Wirth $H$, Hietel B. Heat sensitization to cisplatin in two cell lines with different drug sensitivities. Int J Hyperthermia. 1990:6:47-55.

207. Eichholtzwirth H. Restoration of Cisplatin sensitivity by mild hyperthermia in radiation-induced Cisplatin-resistant mouse fibrosarcoma cells. Int J Oncol. 1995;7:935-9.

208. Raaphorst GP, Doja S, Davis L, Stewart D, Ng CE. A comparison of hyperthermia cisplatin sensitization in human ovarian carcinoma and glioma cell lines sensitive and resistant to cisplatin treatment. Cancer Chemother Pharmacol. 1996;37:574-80.

209. Rietbroek RC, van de Vaart PJ, Haveman J, Blommaert FA, Geerdink A, Bakker PJ, et al. Hyperthermia enhances the cytotoxicity and platinum-DNA adduct formation of lobaplatin and oxaliplatin in cultured SW 1573 cells. J Cancer Res Clin Oncol. 1997;123:6-12

210. Herman TS, Sweets CC, White DM, Gerner EW. Effect of heating on lethality due to hyperthermia and selected chemotherapeutic drugs. J Natl Cancer Inst. 1982:68:487-91.

211. Cohen JD, Robins HI, Javid MJ. Sensitization of C6 glioma to carboplatin cytotoxicity by hyperthermia and thymidine. J Neurooncol. 1990;9:1-8.

212. Ohno S, Siddik ZH, Baba H, Stephens LC, Strebel FR, Wondergem J, et al. Effect of carboplatin combined with whole body hyperthermia on normal tissue and tumor in rats. Cancer Res. 1991:51:2994-3000.

213. Murray TG, Cicciarelli N, McCabe CM, Ksander B, Feuer W, Schiffman J, et al. In vitro efficacy of carboplatin and hyperthermia in a murine retinoblastoma cell line. Invest Ophthalmol Vis Sci. 1997;38:2516-22.

214. Westermann AM, Grosen EA, Katschinski DM, Jäger D, Rietbroek R, Schink JC, et al. A pilot study of whole body hyperthermia and carboplatin in platinumresistant ovarian cancer. Eur J Cancer. 2001:37:1111-7.

215. Song X, Kim S-Y, Lee YJ. The role of Bcl-XL in synergistic induction of apoptosis by mapatumumab and oxaliplatin in combination with hyperthermia on human colon cancer. Mol Cancer Res. 2012;10:1567-79.

216. Dijt FJ, Fichtinger-Schepman AM, Berends F, Reedijk J. Formation and repair of cisplatin-induced adducts to DNA in cultured normal and repair-deficient human fibroblasts. Cancer Res. 1988:48:6058-62

217. Dronkert ML, Kanaar R. Repair of DNA interstrand cross-links. Mutat Res 2001;486:217-47

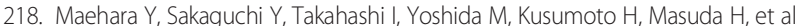
5-Fluorouracil's cytotoxicity is enhanced both in vitro and in vivo by concomitant treatment with hyperthermia and dipyridamole. Cancer Chemother Pharmacol. 1992;29:257-60.

219. Shewach DS, Lawrence TS. Radiosensitization of human tumor cells by gemcitabine in vitro. Semin Oncol. 1995;22:68-71.

220. Crul M, van Waardenburg RCAM, Bocxe S, van Eijndhoven MAJ, Pluim D, Beijnen $\mathrm{JH}$, et al. DNA repair mechanisms involved in gemcitabine cytotoxicity and in the interaction between gemcitabine and cisplatin. Biochem Pharmacol. 2003;65:275-82. 
221. Martin SA, McCarthy A, Barber $\sqcup$, Burgess DJ, Parry S, Lord CJ, et al. Methotrexate induces oxidative DNA damage and is selectively lethal to tumour cells with defects in the DNA mismatch repair gene MSH2. EMBO Mol Med. 2009;1:323-37.

222. Azzam El, Vadasz JA, Raaphorst GP. Thermal sensitivity and radiosensitization in Chinese hamster V79 cells exposed to 2-aminopurine or 6-thioguanine. Radiat Res. 1991;125:223-6.

223. Herman TS, Cress AE, Sweets C, Gerner EW. Reversal of resistance to methotrexate by hyperthermia in Chinese hamster ovary cells. Cancer Res. 1981;41:3840-3.

224. Ng CE, Bussey AM, Raaphorst GP. Sequence of treatment is important in the modification of camptothecin induced cell killing by hyperthermia. Int J Hyperthermia. 1996;12:663-78. discussion 679-80.

225. Bentle MS, Reinicke KE, Dong Y, Bey EA, Boothman DA. Nonhomologous end joining is essential for cellular resistance to the novel antitumor agent, betalapachone. Cancer Res. 2007;67:6936-45.

226. Pommier Y, Redon C, Rao VA, Seiler JA, Sordet O, Takemura H, et al. Repair of and checkpoint response to topoisomerase I-mediated DNA damage. Mutat Res. 2003;532:173-203.

227. Ohnoshi T, Ohnuma T, Beranek JT, Holland JF. Combined cytotoxicity effect of hyperthermia and anthracycline antibiotics on human tumor cells. J Natl Cancer Inst. 1985;74:275-81.

228. Supino R, Bardella L, Gibelli N, Cairo G, Schiaffonati L. Interaction of heat with chemotherapy in vitro: effect on cell viability and protein synthesis in human and murine cell lines. Tumori. 1987;73:109-16.

229. Hermisson M, Weller M. Hyperthermia enhanced chemosensitivity of human malignant glioma cells. Anticancer Res. 2000;20:1819-23.

230. Lee H, Kim S, Choi B-H, Park M-T, Lee J, Jeong S-Y, et al. Hyperthermia improves therapeutic efficacy of doxorubicin carried by mesoporous silica nanocontainers in human lung cancer cells. Int J Hyperthermia. 2011;27:698-707.

231. Adachi N, liizumi S, So S, Koyama H. Genetic evidence for involvement of two distinct nonhomologous end-joining pathways in repair of topoisomerase II-mediated DNA damage. Biochem Biophys Res Commun. 2004;318:856-61

232. Malik M, Nitiss KC, Enriquez-Rios V, Nitiss JL. Roles of nonhomologous end-joining pathways in surviving topoisomerase I-mediated DNA damage. Mol Cancer Ther. 2006;5:1405-14.

233. Treszezamsky AD, Kachnic LA, Feng Z, Zhang J, Tokadjian C, Powell SN BRCA1- and BRCA2-deficient cells are sensitive to etoposide-induced DNA double-strand breaks via topoisomerase II. Cancer Res. 2007;67:7078-81.

234. Murzik U, Hemmerich P, Weidtkamp-Peters S, Ulbricht T, Bussen W, Hentschel J, et al. Rad54B targeting to DNA double-strand break repair sites requires complex formation with S100A11. Mol Biol Cell. 2008;19:2926-35.

235. Norbury CJ, Hickson ID. Cellular responses to DNA damage. Annu Rev Pharmacol Toxicol. 2001:41:367-401.

236. Hahn GM, Braun J, Har-Kedar I. Thermochemotherapy: synergism between hyperthermia (42-43 degrees) and adriamycin (of bleomycin) in mammalian cell inactivation. Proc Natl Acad Sci U S A. 1975;72:937-40

237. Dahl O, Mella O. Enhanced effect of combined hyperthermia and chemotherapy (bleomycin, BCNU) in a neurogenic rat tumour (BT4A) in vivo. Anticancer Res. 1982;2:359-64.

238. Farmer H, McCabe N, Lord CJ, Tutt ANJ, Johnson DA, Richardson TB, et al. Targeting the DNA repair defect in BRCA mutant cells as a therapeutic strategy. Nature. 2005:434:917-21.

239. Bryant HE, Schultz $N$, Thomas HD, Parker KM, Flower D, Lopez E, et al. Specific killing of BRCA2-deficient tumours with inhibitors of poly(ADP-ribose) polymerase. Nature. 2005;434:913-7.

240. Davar D, Beumer JH, Hamieh L, Tawbi H. Role of PARP inhibitors in cancer biology and therapy. Curr Med Chem. 2012;19:3907-21.

\section{Submit your next manuscript to BioMed Central and take full advantage of:}

- Convenient online submission

- Thorough peer review

- No space constraints or color figure charges

- Immediate publication on acceptance

- Inclusion in PubMed, CAS, Scopus and Google Scholar

- Research which is freely available for redistribution 